\author{
ARTUR TOMANEK \\ ORCID: 0000-0002-3287-5886 \\ Uniwersytet Wrocławski \\ Instytut Prawa Cywilnego \\ Zakład Prawa Pracy
}

\title{
STATUS WSPÓLNIKA SPÓŁKI HANDLOWEJ JAKO TYTUŁ UBEZPIECZENIA SPOŁECZNEGO
}

\begin{abstract}
Abstrakt: Opracowanie podejmuje zagadnienie statusu wspólników spółek handlowych w aspekcie obowiązku ubezpieczenia społecznego. Analiza ta wykazuje brak spójnej koncepcji ustawodawczej. Skorygowania wymaga podmiotowy zasięg obowiązku ubezpieczenia wspólników niektórych spółek osobowych — spółki komandytowej i spółki komandytowo-akcyjnej. Ponadto status wspólnika jako tytuł ubezpieczenia społecznego nie jest powiązany z prowadzeniem przez spółkę działalności gospodarczej. W przypadku wspólników spółek kapitałowych ubezpieczenie społeczne powinno być natomiast wyjątkiem od reguły nieubezpieczenia. Ubezpieczeniu społecznemu nie powinien podlegać kapitał, lecz praca lub działalność zarobkowa.
\end{abstract}

Słowa kluczowe: system ubezpieczeń społecznych, ubezpieczenie obowiązkowe, spółka handlowa, spółka kapitałowa, wspólnik, działalność gospodarcza

\section{ZAKRES PODMIOTOWY REGULACJI PRAWNEJ}

Zakres podmiotowy ubezpieczenia społecznego wspólników spółek handlowych jest regulowany przez art. 8 ust. 6 pkt 4 i 4a ustawy z dnia 13 października 1998 roku o systemie ubezpieczeń społecznych ${ }^{1}$. W art. 8 ust. 6 pkt 4 tej ustawy wymieniono wspólnika jednoosobowej spółki z ograniczoną odpowiedzialnością oraz wspólników spółki jawnej, komandytowej lub partnerskiej, w nowo zaś dodanym $^{2}$ (z mocą od dnia 1 marca 2020 roku) punkcie 4a tego przepisu — akcjonariusza prostej spółki akcyjnej wnoszącego do spółki wkład, którego przedmiotem jest świadczenie pracy lub usług. Osoby te są objęte obowiązkowymi ubezpieczeniami

1 Tekst jedn. Dz.U. z 2019 r. poz. 300 ze zm. (dalej: u.s.o.s.).

2 Nowelizacja została dokonana ustawą z dnia 19 lipca 2019 roku o zmianie ustawy - Kodeks spółek handlowych oraz niektórych innych ustaw (Dz.U. poz. 1655). 
— emerytalnym, rentowym i wypadkowym, natomiast na swój wniosek (dobrowolnie) mogą przystąpić do ubezpieczenia chorobowego ${ }^{3}$.

Ewolucja przepisów ustawy systemowej doprowadziła do sprecyzowania i poszerzenia kategorii wspólników spółek handlowych podlegających obowiązkowym ubezpieczeniom społecznym. W pierwszej fazie obowiązywania tej ustawy nie wymieniała ona oddzielnie tych ubezpieczonych. Uznawano jednak, że wspólnicy spółek osobowych — spółki jawnej i spółki komandytowej — podlegają ubezpieczeniom jako osoby prowadzące pozarolniczą działalność gospodarczą. Mimo sprzeciwu zgłoszonego w doktrynie prawa handlowego ${ }^{4}$ wykładnia ta została podtrzymana przez judykaturę po 1 stycznia 2001roku, kiedy to kodeks handlowy $^{5}$ został zastąpiony przez ustawę z dnia 15 września 2000 roku — Kodeks spółek handlowych ${ }^{6}$, a jednocześnie weszła w życie ustawa z dnia 19 listopada 1999 roku — Prawo działalności gospodarczej ${ }^{7}$ w świetle której wspólnicy spółek handlowych nie mogli być nadal uznawani za przedsiębiorców. Od tego czasu przymiot ten przysługuje wyłącznie spółce handlowej. Natomiast w art. 1 k.s.h. uregulowano normatywnie pojęcia spółki osobowej i kapitałowej, dołączając do tej pierwszej grupy nowe rodzaje spółek: spółkę partnerską oraz spółkę komandytowo-akcyjną.

Ustawodawca ubezpieczeniowy zareagował na wskazane zmiany stanu prawnego po przeszło dwóch latach, na drodze ustawy z dnia 18 grudnia 2002 roku o zmianie ustawy o systemie ubezpieczeń społecznych oraz o zmianie niektórych ustaw $^{8}$ nadającej obecny kształt art. 8 ust. 6 pkt 4 u.s.o.s. Nowelizacja ta doprowadziła do wyraźnego oddzielenia wspólników spółek handlowych od osób fizycznych prowadzących pozarolniczą działalność gospodarczą, pozostawiając obie te grupy w ramach szerszej kategorii pojęciowej podmiotów ubezpieczenia obowiązkowego — „osób prowadzących pozarolniczą działalność"9. W świetle treści tego przepisu, przedstawionej na wstępie niniejszych rozważań, ubezpieczenie

3 Art. 11 ust. 2 u.s.o.s.

${ }^{4}$ P. Bielski, Obowiazek ubezpieczenia społecznego wspólników spółek handlowych — problem modelu regulacji prawnej, „Rejent” 2003, nr 7-8, s. 41-56; idem, Objęcie wspólników spótki jawnej prowadzacych działalność gospodarcza obowiąziem ubezpieczenia społecznego, „Prawo Spółek" 2006, nr 9, s. 57.

5 Rozporządzenie Prezydenta Rzeczypospolitej z dnia 27 czerwca 1934 roku - Kodeks handlowy, Dz.U. Nr 57, poz. 502 ze zm.

6 Tekst jedn. Dz.U. z 2019 roku poz. 505 ze zm.

7 Tekst jedn. Dz.U. z 2017 roku poz. 2168 ze zm. (dalej: u.s.dz.g.). Z dniem 30 kwietnia 2018 roku ustawa ta została zastąpiona przez ustawę z 6 marca 2018 roku — Prawo przedsiębiorców, Dz.U. poz. 650 ze zm. (dalej: u.p.przeds.)

8 Dz.U. Nr 241, poz. 2074.

9 Do osób prowadzących pozarolniczą działalność ustawodawca zaliczył ponadto: twórcę i artystę, osobę prowadzącą działalność w ramach wolnego zawodu oraz osobę prowadzącą publiczną lub niepubliczną szkołę, inną formę wychowania przedszkolnego, placówkę lub ich zespół, na podstawie przepisów ustawy z dnia 14 grudnia 2016 roku — Prawo oświatowe (art. 8 ust. 6 pkt 2, 3, 5 ustawy systemowej). 
obowiązkowe obejmuje wspólników wszystkich spółek osobowych poza spółką komandytowo-akcyjną. Odmienną logikę zastosowano w odniesieniu do wspólników spółek kapitałowych, obejmując ubezpieczeniem obowiązkowym wyłącznie dwie kategorie podmiotów - wspólników jednoosobowych spółek z ograniczoną odpowiedzialnością, a następnie akcjonariuszy prostej spółki akcyjnej wnoszących do spółki wkład, którego przedmiotem jest świadczenie pracy lub usług. Zróżnicowanie metod regulacji prawnej, którymi posłużono się w powołanym przepisie ustawy systemowej, polega więc na tym, że w przypadku wspólników spółek osobowych punktem odniesienia obowiązku ubezpieczenia uczyniono wyłącznie rodzaj spółki, natomiast w odniesieniu do spółek kapitałowych wskazuje się szczególne cechy wspólników podlegających ubezpieczeniu.

Odnośnie do spółek osobowych założenie przyjęte przez ustawodawcę budzi wątpliwości w przypadku wspólników spółki komandytowej, o których jest mowa w art. 8 ust. 6 pkt 4 u.s.o.s., a także wspólników spółki komandytowo-akcyjnej, którzy nie zostali wymienieni w powyższym przepisie. W obu tych spółkach uczestniczą komplementariusze (wspólnicy jawni) oraz komandytariusze - wspólnicy, których odpowiedzialność za zobowiązania spółki ogranicza się do sumy komandytowej (art. 111 k.s.h.). W odróżnieniu od komplementariusza komandytariusz nie reprezentuje spółki komandytowej, wyłączając działanie na podstawie pełnomocnictwa (art. $118 \S 1$ k.s.h.), a także nie ma prawa ani obowiązku prowadzenia spraw spółki, chyba że umowa spółki stanowi inaczej (art. 121 $\S 1$ k.s.h.). W typowej spółce komandytowej komandytariuszowi przypada zatem rola podmiotu lokującego w spółce swój kapitał, niemającego natomiast czynnego udziału w zarządzaniu spółką. Te elementy przemawiają przeciwko objęciu komandytariusza ubezpieczeniami społecznymi, jeżeli przyjąć założenie, że celem ustawodawcy było ubezpieczenie osób prowadzących działalność zarobkową (nazwaną w ustawie systemowej jako „pozarolnicza działalność”), nie zaś osób, których udział w podmiocie gospodarczym (spółce) ma charakter kapitałowy. Należy jednak pamiętać, że model funkcjonowania spółki komandytowej może być zmieniony decyzją wspólników. W szczególności możliwe jest przyznanie komandytariuszowi, na równi z komplementariuszem, prawa prowadzenia spraw spółki, udzielenie mu prokury (co zbliża jego pozycję w sferze zarządzania spółki do komplementariusza), a nawet zamieszczenie jego nazwiska w firmie spółki, wskutek czego uchylone są wszelkie ograniczenia odpowiedzialności wobec osób trzecich (art. $104 \S 4$ zd. 2. k.s.h.). Ustawodawca z zakresu ubezpieczeń społecznych zdecydował o jednolitym ukształtowaniu statusu komandytariuszy w sferze obowiązku ubezpieczenia społecznego, obejmując ich zasadami takimi samymi jak wspólników spółki jawnej i spółki partnerskiej.

Nie wywołuje natomiast zastrzeżeń objęcie ubezpieczeniami społecznymi komplementariusza w spółce komandytowej, którego pozycja odpowiada statusowi wspólnika spółki jawnej. Tym większe zdziwienie budzi jednak to, że analogiczna decyzja ustawodawcza nie została rozciągnięta na komplementariuszy 
W spółce komandytowo-akcyjnej ${ }^{10}$. W spółce tej co najmniej jeden wspólnik odpowiada bez ograniczenia (komplementariusz), a co najmniej jeden wspólnik jest akcjonariuszem (art. 125 k.s.h.). Ponadto możliwe jest, ze wspólnik posiada „podwójny" status, jeżeli, będąc komplementariuszem, nabył akcje spółki ${ }^{11}$. Trafne jest odstąpienie od ubezpieczenia społecznego wspólnika spółki komandytowo-akcyjnej będącego wyłącznie jej akcjonariuszem, skoro jego uprawnienia wobec spółki mają charakter stricte kapitałowy. Jednak w zakresie stosunku prawnego komplementariuszy, zarówno między sobą, wobec wszystkich akcjonariuszy, jak i wobec osób trzecich, a także wkładów tychże wspólników do spółki, z wyłączeniem wkładów na kapitał zakładowy, stosuje się odpowiednio przepisy dotyczące spółki jawnej (art. $126 \S 1$ pkt 1 k.s.h.). Oznacza to, że pozycja prawna komplementariusza w spółce komandytowo-akcyjnej nie odbiega istotnie od pozycji wspólnika w spółce jawnej lub komplementariusza w spółce komandytowej, przy czym można w tym miejscu pominąć szczegóły odnośnych uregulowań k.s.h., które nie powinny mieć rozstrzygającego znaczenia z punktu widzenia ochrony przyznawanej przez przepisy prawa ubezpieczeń społecznych. Dla wyrażonego tutaj stanowiska nie jest bez znaczenia, że kodeksowa koncepcja spółki komandytowo-akcyjnej została oparta na modelu, który kładzie akcent na elementy spółki komandytowej ${ }^{12}$.

Biorąc pod uwagę całość regulacji art. 8 ust. 6 pkt 4 u.s.o.s., status wspólnika spółki komandytowo-akcyjnej w sferze ubezpieczeń społecznych powinien być zróżnicowany w zależności od tego, czy mamy do czynienia z komandytariuszem, czy akcjonariuszem tej spółki. Ubezpieczenia obowiązkowe powinny być adresowane do komplementariuszy spółek komandytowo-akcyjnych, i to niezależnie od tego, czy komplementariusz jest jednocześnie akcjonariuszem spółki. Takiego wniosku niepodobna wyprowadzić z brzmienia powołanego przepisu, w którym pominięto w ogólności wspólników spółki komandytowo-akcyjnej. Nie może być zaś mowy o analogicznym stosowaniu rozwiązań zawartych w u.s.o.s. do wspólników wymienionych spółek, skoro przepis art. 8 ust. 6 pkt 4 tej ustawy ma enumeratywny charakter i odwołuje się bezpośrednio do terminologii prawa spółek poprzez wyliczenie określonych typów spółek, wobec czego terminom tym można nadać jedynie takie znaczenie, jakie jest określone w tej gałęzi prawa. Nie można zatem oprzeć się wrażeniu, że krytykowana tutaj decyzja ustawodawcy nosi znamiona uznaniowości w pejoratywnym tego słowa znaczeniu oraz wynika z niepogłębionej oceny wewnętrznej struktury spółki komandytowo-akcyjnej.

10 Dostrzegł to również P. Bielski, Obowiazek ubezpieczenia społecznego..., s. 50. Zob. też B. Gudowska, [w:] Ustawa o systemie ubezpieczeń spotecznych. Komentarz, red. B. Gudowska, J. Strusińska-Żukowska, Warszawa 2011, s. 226.

11 Zob. A. Kidyba, Handlowe spótki osobowe, Warszawa 2013, s. 465, 476-477.

12 Tak A. Szumański, [w:] Kodeks spótek handlowych, t. 1. Przepisy ogólne. Spótki osobowe, red. S. Sołtysiński et al., Warszawa 2012, s. 968-975; R. Lewandowski, Polska koncepcja legislacyjna spótki komandytowo-akcyjnej, Warszawa 2007, s. 41-42. 
Innego rodzaju uwagi budzi odniesienie obowiązkowego ubezpieczenia społecznego do wyróżnionych ustawowo kategorii wspólników spółek kapitałowych. Ustawodawca dokonał wyłomu w ramach pierwotnego założenia o pozostawieniu wspólników tych spółek poza zakresem ubezpieczeń obowiązkowych. Pierwszym i zasadniczym odstępstwem było objęcie tymi ubezpieczeniami wspólników jednoosobowych spółek z ograniczoną odpowiedzialnością, co nastąpiło od 1 stycznia 2003 roku. Jak wynika $z$ uzasadnienia projektu ustawy nowelizacyjnej z dnia 18 grudnia 2002 roku, przesłanką wprowadzenia tego rozwiązania była chęć udzielenia ochrony ubezpieczeniowej wspólnikom spółek jednoosobowych, którzy zgłaszali się do ubezpieczenia jako pracownicy spółki, jednak odmawiano objęcia ich ubezpieczeniami społecznymi, jako że nie mogli skutecznie zawrzeć umowy „sami ze sobą"13.

Rozszerzenie obowiązkowego ubezpieczenia społecznego na wspólników jednoosobowych spółek z ograniczoną odpowiedzialnością spotkało się ze zróżnicowanym przyjęciem doktryny. W piśmiennictwie z zakresu prawa spółek należy odnotować głos krytyczny, podkreślający że wspólnik spółki jednoosobowej nie prowadzi działalności gospodarczej, i to bez względu na to, czy jest on jednocześnie członkiem jej zarządu. Jedynie ta spółka może być uznana za przedsiębiorcę i ze względu na wskazaną cechę nie różni się ona od wieloosobowej spółki z o. o. ${ }^{14}$ Natomiast wypowiedź przedstawiciela nauki prawa pracy i ubezpieczeń społecznych wskazuje na pozytywną ocenę dokonanej zmiany. Według Z. Hajna unormowanie to potwierdza trafność tezy o niemożności pogodzenia właścicielskiego i pracowniczego statusu jedynych udziałowców spółki z o. o. ${ }^{15}$

W wyroku z dnia 25 września 2014 roku, SK 4/12 ${ }^{16}$, Trybunał Konstytucyjny stwierdził, że art. 8 ust. 6 pkt 4 u.s.o.s. w zakresie odnoszącym się do wspólnika jednoosobowej spółki z ograniczoną odpowiedzialnością jest zgodny z art. 64 ust. 2 w związku $\mathrm{z}$ art. 32 ust. 1 Konstytucji RP. W szczególności Trybunał nie podzielił stanowiska skarżącej, że zróżnicowanie statusu ubezpieczeniowego wspólnika spółki z o.o. w zależności od jednoosobowego lub wieloosobowego charakteru spółki jest sprzeczne z nakazem równej ochrony wynikającym z art. 64 ust. 2 Konstytucji. Orzeczenie to nie może być jednak traktowane jako zamknięcie problemu. Po pierwsze, badanie konstytucyjności wskazanego przepisu miało ograniczony charakter, co wynikało z zakresu zarzutów skargi. Po drugie zaś stwierdzenie, że analizowane rozwiązanie nie narusza przepisów Konstytucji, nie jest tożsame z oceną, że jego obecny kształt jest racjonalny.

13 Rządowy projekt ustawy o zmianie ustawy o systemie ubezpieczeń społecznych oraz o zmianie niektórych innych ustaw, druk nr 700 Sejmu IV kadencji.

14 P. Bielski, Obowiązek ubezpieczenia społecznego..., s. 44.

15 Z. Hajn, Zatrudnienie (się) we własnym zakładzie pracy $w$ świetle ustrojowych zasad prawa pracy, [w:] Współczesne problemy prawa pracy i ubezpieczeń społecznych, red. L. Florek, Ł. Pisarczyk, Warszawa 2011, s. 198.

16 Dz.U. z 2014 r. poz. 1366, OTK-A 2014, nr 8, poz. 95. 
PROWADZENIE DZIAŁALNOŚCI W RAMACH SPÓŁKI HANDLOWEJ A OBOWIĄZEK UBEZPIECZENIA SPOŁECZNEGO WSPÓLNIKA

Dla statusu wspólników spółek handlowych w dziedzinie ubezpieczeń społecznych istotna jest zbiorcza kategoria „osób prowadzących pozarolniczą działalność" (art. 8 ust. 6 u.s.o.s.), do której poza interesującą nas grupą wspólników zaliczone zostały między innymi osoby fizyczne prowadzące pozarolniczą działalność gospodarczą na podstawie przepisów o działalności gospodarczej lub innych przepisów szczególnych. Okres podlegania ubezpieczeniom przez osoby prowadzące pozarolniczą działalność został ukształtowany jednolicie w art. 13 pkt 4 u.s.o.s. poza wyjątkiem odnoszącym się do wspólnika prostej spółki akcyjnej ${ }^{17}$. Przepis ten stanowi, że wymienione osoby podlegają ubezpieczeniom od dnia rozpoczęcia wykonywania działalności do dnia zaprzestania wykonywania tej działalności - z wyłączeniem okresu, na który wykonywanie działalności zostało zawieszone na podstawie art. 36aa u.s.o.s. oraz przepisów u.p.przeds. Jednolitość ta ma jednak charakter pozorny. W przypadku przedsiębiorców indywidualnych chodzi bowiem o okres prowadzenia we własnym imieniu, w sposób ciągły, zorganizowanej działalności zarobkowej (art. 3 u.p.przeds.). Natomiast w przypadku wspólników spółek handlowych „działalnością” podlegającą ubezpieczeniu jest sam status wspólnika spółki, co wynika wprost z przytoczonego art. 8 ust. 6 pkt 4 u.s.o.s.

Dla obowiązku ubezpieczenia społecznego osoby fizycznej prowadzącej działalność gospodarczą istotny jest natomiast fakt rzeczywistego prowadzenia przez nią takiej działalności. Sam wpis do ewidencji tej działalności ma charakter deklaratoryjny, a nie konstytutywny. Nie kreuje on bytu prawnego przedsiębiorcy. Określenie przez przedsiębiorcę daty rozpoczęcia działalności gospodarczej wpisywanej do ewidencji skutkuje domniemaniem faktycznym, że z tą datą działalność gospodarcza została podjęta i była prowadzona aż do czasu jej wykreślenia $\mathrm{z}$ ewidencji. Domniemanie to może być jednak obalone ${ }^{18}$.

Te założenia odnoszące się do osób prowadzących indywidualną działalność gospodarczą nie mogą być przenoszone na sferę obowiązkowego ubezpieczenia wspólników spółek handlowych. Wspólnik spółki handlowej nie ma bowiem, w zakresie wynikającym z więzi korporacyjnej, przymiotu osoby prowadzącej działalność gospodarczą. Przymiot ten przysługuje spółce, a nie jej wspólnikowi, bez względu na to, czy jest on uprawniony — w spółkach osobowych — do pro-

17 Zgodnie z art. 13 pkt 5a u.s.o.s., dodanym z mocą od dnia 1 marca 2020 roku, wspólnik ten podlega ubezpieczeniu od dnia rozpoczęcia świadczenia pracy lub usług w zamian za akcje objęte w spółce do dnia zakończenia ich świadczenia.

18 Zob. między innymi wyrok NSA z dnia 25 października 2006 roku, II GSK 179/06, LEX nr 276729; wyrok SN z dnia 14 września 2007 roku, III UK 35/07, LEX nr 483284; wyrok SN z dnia 12 stycznia 2012 roku, I UK 203/11, LEX nr 1162649; wyrok SN z dnia 8 listopada 2017 roku, III UK 244/16, LEX nr 2428259. 
wadzenia spraw spółki. Oderwanie statusu wspólnika od działalności wykonywanej w ramach spółki zostało uznane w przepisach prawa ubezpieczeń społecznych, a w szczególności w przytoczonym art. 8 ust. 6 pkt 4 u.s.o.s., który wiąże pojęcie „działalności pozarolniczej” ze statusem wspólnika spółki handlowej, niezależnie od tego, czy w ramach tej spółki prowadzona jest działalność gospodarcza.

Stanowisko to zostało ugruntowane w licznych rozstrzygnięciach sądów powszechnych i administracyjnych. W wyroku z dnia 13 września 2010 roku, II UK $82 / 10^{19}$, Sąd Najwyższy stwierdził wprost, że wykonywanie pozarolniczej działalności, o której stanowi art. 13 ust. 4 u.s.o.s., to nic innego, jak posiadanie statusu wspólnika spółki komandytowej prowadzącej działalność gospodarczą. Podleganie przez wspólnika takiej spółki obowiązkowo ubezpieczeniom społecznym w okresie od dnia rozpoczęcia wykonywania działalności pozarolniczej do dnia zaprzestania jej wykonywania należy zatem odnosić do okresu posiadania statusu wspólnika w spółce prowadzącej (wykonującej) działalność gospodarczą, a nie do faktycznego uczestniczenia w działalności przedsiębiorstwa ${ }^{20}$. Również w wyroku SN z dnia 3 lutego 2011 roku, II UK 271/10²1, uznano, że obowiązek ubezpieczenia wspólnika jednoosobowej spółki z o.o. jest powiązany jedynie z posiadaniem przez niego takiego statusu prawnego, a nie z prowadzeniem działalności gospodarczej. Analogiczne stanowisko zajmują sądy administracyjne ${ }^{22}$. Następstwem tak ukształtowanej linii orzeczniczej jest stwierdzenie, że komandytariusz przystępujący do spółki komandytowej podlega ubezpieczeniom społecznym od dnia przystąpienia do tej spółki, a nie z dniem wpisu wspólnika (komandytariusza) do rejestru przedsiębiorców prowadzonego dla spółki²3. Konsekwentnie należy przyjąć, że wspólnik spółki handlowej podlega obowiązkowym ubezpieczeniom społecznym bez względu na wydanie wobec niego przez sąd karny ${ }^{24}$ lub upadłościowy ${ }^{25}$ orzeczenia pozbawiającego go prawa prowadzenia działalności gospodarczej, albowiem orzeczenie to nie ma wpływu na status wspólnika i wynikające z niego prawa i obowiązki.

Innym aspektem rozpatrywanego zagadnienia jest wpływ faktycznego prowadzenia działalności przez spółkę handlową na obowiązek ubezpieczenia społecznego wspólnika tej spółki. Kwestia ta jest praktycznie doniosła. Po pierwsze, spółka z ograniczoną odpowiedzialnością może być zawiązana również w celu pozagospodarczym ${ }^{26}$, przez co nie wykazuje ona cech przedsiębiorcy w rozumieniu

19 OSNP 2012, nr 1-2, poz. 21

${ }^{20}$ Podobnie wyrok SN z dnia 7 grudnia 2012 roku, II UK 121/12, OSNP 2013, nr 23-24, poz. 281.

21 LEX nr 817528.

22 Wyrok NSA z dnia 26 lipca 2017 roku, II GSK 3136/15, LEX nr 2348874; wyrok WSA w Warszawie z dnia 27 maja 2016 roku, VI SA/Wa 2736/15, LEX nr 2113763.

${ }^{23}$ OSNP 2013, nr 5-6, poz. 60.

24 Zob. art. 41 § 2 k.k.

25 Zob. art. 373 i 374 ustawy z dnia 28 lutego 2003 roku - Prawo upadłościowe, tekst jedn. Dz.U. z 2019 r. poz. 498 ze zm.

26 Jak wynika $\mathrm{z}$ art. $151 \S 1$ k.s.h. 
wskazanego przepisu, choć formalnie podlega wpisowi do rejestru przedsiębiorców. Po drugie, w obrocie funkcjonuje wiele „martwych” spółek handlowych, które nie prowadzą żadnej działalności. Po trzecie, powstaje problem, czy wspólnik spółki handlowej podlega ubezpieczeniom obowiązkowym w okresie zawieszenia przez spółkę działalności gospodarczej na podstawie art. 23 ust. 2 u.p.przeds. ${ }^{27}$

Gramatyczna wykładnia przepisów ustawy systemowej skłania do oceny, że okoliczność faktycznego prowadzenia przez spółkę działalności jest obojętna z punktu widzenia ubezpieczenia społecznego jej wspólnika. Jedynym, co wpływa na istnienie omawianego tytułu ubezpieczenia, jest status wspólnika, pojmowany w oderwaniu od działalności spółki. Zawieszenie przez spółkę handlową wykonywania działalności gospodarczej nie powoduje wyłączenia wspólnika z ubezpieczenia. Działalnością pozarolniczą podlegającą ubezpieczeniu jest bowiem status wspólnika, który jest niezmienny bez względu na to, czy spółka prowadzi aktywną działalność gospodarczą.

Określając zakres podmiotowy ubezpieczenia społecznego, przepis art. 8 ust. 6 pkt 4 ustawy systemowej wymienia wspólnika spółki z ograniczoną odpowiedzialnością, nie różnicując tego zakresu ze względu na to, czy przedmiot działania spółki obejmuje prowadzenie działalności gospodarczej, czy też spółka została założona $\mathrm{w}$ innym celu prawnie dopuszczalnym (art. $151 \S 1$ k.s.h.). Nic innego nie wynika z wykładni systemowej, skoro wspólnicy zostali zaliczeni do „osób prowadzących działalność pozarolniczą", bez powiązania jej z działalnością gospodarczą, jak w przypadku podkategorii osób fizycznych prowadzących taką działalność na podstawie ustawy - Prawo przedsiębiorców (art. 8 ust. 6 pkt 1 u.s.o.s.). Można oczywiście uznać, że zasygnalizowana kwestia ma znikomą doniosłość praktyczną, ponieważ dotyczy wyłącznie wspólników jednoosobowych spółek z ograniczoną odpowiedzialnością, a nie wspólników spółek osobowych ${ }^{28}$, jednak konstatacja ta nie rozwiązuje problemu.

Wśród wypowiedzi judykatury warto zwrócić uwagę na wyrok Sądu Apelacyjnego w Lublinie z dnia 22 lutego 2018 roku, III AUa 691/1729, odnoszący się do wspólnika spółki jawnej, która zaprzestała faktycznie prowadzenia działalności gospodarczej bez dokonania jakichkolwiek zmian w rejestrze przedsiębiorców. Sąd ocenił, że przez fakt bycia wspólnikiem nieistniejącej faktycznie spółki, która nie została wykreślona z właściwego rejestru, nie nabywa się tytułu ubezpieczenia społecznego. Nie można mówić o samodzielnej podstawie podlegania ubezpieczeniu

27 Zgodnie z art. 23 ust. 2 u.p.przeds, przedsiębiorca wpisany do rejestru przedsiębiorców Krajowego Rejestru Sądowego może zawiesić wykonywanie działalności gospodarczej na okres od 30 dni do 24 miesięcy. Poprzednio analogiczne rozwiązanie zawierał art. 14a u.s.dz.g.

${ }^{28}$ Spółki osobowe są zakładane w celu prowadzenia przedsiębiorstwa (art. $22 \S 1$ k.s.h., art. 86 $\S 1$ k.s.h., art. 102 k.s.h., art. 125 k.s.h.). Prosta spółka akcyjna może być wprawdzie zawiązana w innym celu (art. $300^{1} \S 1$ k.s.h.), jednak ratio legis obowiązku ubezpieczenia społecznego wspólnika tej spółki jest wykonywanie przez niego pracy lub usług na rzecz spółki.

29 LEX nr 2455114. 
społecznemu wynikającej wyłącznie z wpisu do ewidencji prowadzenia działalności gospodarczej czy wpisu w Krajowym Rejestrze Sądowym. Uzasadnienie tego judykatu budzi jednak wątpliwości. Sąd uznał błędnie, że obowiązkowym tytułem ubezpieczenia emerytalnego i rentowego wspólników jest, stosownie do art. 6 ust. 1 pkt 5 u.s.o.s., prowadzenie pozarolniczej działalności gospodarczej, podczas gdy przepis ten mówi jedynie o osobach prowadzących pozarolniczą działalność, do których należą zarówno przedsiębiorcy, jak i podmioty niebędące przedsiębiorcami, w tym wspólnicy spółek handlowych, a także twórcy i artyści (art. 6 ust. 5 pkt 2 u.s.o.s.).

Wpływem zawieszenia działalności gospodarczej spółki komandytowej na obowiązek ubezpieczenia społecznego wspólnika (komandytariusza) tej spółki zajmował się Sąd Najwyższy w powołanym wyroku z dnia 13 września 2010 roku, II UK 82/10. Sąd ten wskazał, że w okresie zawieszenia działalności przez spółkę komandytową, na podstawie art. 14a u.s.dz.g., jej wspólników „nie można uznać za osoby prowadzące pozarolniczą działalność poprzez pozostawanie wspólnikami spółki prowadzącej (wykonującej) działalność gospodarczą". Wspólnicy spółki komandytowej nie są bowiem przedsiębiorcami, a więc jedynie spółka jest uprawniona do zawieszenia działalności gospodarczej. Zawieszenie działalności przez spółkę wywołuje zaś skutek wobec wszystkich jej wspólników w zakresie podlegania ubezpieczeniom społecznym.

Odnosząc się do tego poglądu, należy zauważyć, że rozmija się on de lege lata z brzmieniem przepisu ustawy o systemie ubezpieczeń społecznych stanowiącego podstawę obowiązku ubezpieczenia społecznego wspólników spółek handlowych. Wprawdzie w art. 13 pkt 4 tej ustawy wyłączono obowiązek ubezpieczenia społecznego w okresie, „na który wykonywanie działalności [pozarolniczej A.T.] zostało zawieszone na podstawie przepisów o działalności gospodarczej”. Jednakże za powołanymi wcześniej orzeczeniami sądowymi należy powtórzyć, że w przypadku wspólników działalnością pozarolniczą podlegającą ubezpieczeniu jest sam status wspólnika, a nie prowadzenie działalności gospodarczej, tym bardziej zaś prowadzenie jej przez spółkę. Prowadzi to do wniosku, że przytoczony fragment art. 13 pkt 4 u.s.o.s., w którym jest mowa o zawieszeniu wykonywania działalności gospodarczej, nie dotyczy działalności obejmującej status wspólnika spółki handlowej. Wyprowadzanie odmiennych wniosków na zasadzie analogii wydaje się wątpliwe. Przy wykładni przepisów prawa ubezpieczeń społecznych prymat przysługuje językowym dyrektywom interpretacyjnym, zwłaszcza jeżeli nie można jednoznacznie stwierdzić, że ustalona w ten sposób treść przepisu nie odpowiada woli ustawodawcy. Ponadto poszukiwanie tytułu ubezpieczenia społecznego, jak również podstaw do wyłączenia tego tytułu, nie powinno odbywać się poprzez analogię ${ }^{30}$. Można również zarzucić wewnętrzną niespójność stanowiska zakładającego, że faktyczne uczestniczenie przez wspólnika w dzia-

30 Tak trafnie SN w uzasadnieniu wyroku z dnia 17 października 2017 roku, II UK 451/16, LEX nr 2427158. 
łalności gospodarczej spółki jest pozbawione wpływu na ubezpieczenie społeczne wspólnika, natomiast prowadzenie działalności gospodarczej przez samą spółkę miałoby mieć taki wpływ. Prowadzenie działalności gospodarczej przez spółkę osobową jest — prawie zawsze — wykładnikiem osobistego zaangażowania jej wspólników.

Podsumowując dotychczasowe rozważania, należy stwierdzić, że w świetle obowiązujących obecnie przepisów brakuje wyraźnych podstaw do wyłączenia obowiązku ubezpieczenia społecznego wspólnika spółki handlowej w okresach, kiedy wspólnik nie wykazuje aktywności w sprawach spółki, jak i w razie braku faktycznego (rzeczywistego) prowadzenia statutowej działalności spółki.

\section{WNIOSKI}

Ograniczony zakres tego opracowania pozwolił jedynie na zarysowanie złożonej problematyki ubezpieczenia społecznego wspólników spółek handlowych. Przeprowadzone rozważania upoważniają jednak do postawienia tezy, że istniejący w tej dziedzinie stan regulacji prawnej odbiega od rozwiązań, których należałoby oczekiwać od racjonalnego pracodawcy.

Wydaje się, że obowiązujący stan prawny ukazuje brak wyraźnej koncepcji ustawodawczej co do zasięgu podmiotowego ubezpieczenia społecznego wspólników spółek handlowej. W mojej ocenie ubezpieczenie obowiązkowe powinno obejmować osoby, które w ramach posiadanego przez nie statusu wykonują pracę lub działalność zarobkową. W przypadku wspólników spółek kapitałowych oznacza to konieczność ściślejszego rozdzielenia pomiędzy sytuacjami, w których zaangażowanie wspólnika ma charakter osobisty lub kapitałowy. Modelowi zaangażowania osobistego odpowiada status wspólnika spółki osobowej, przy czym bardziej wnikliwego przemyślenia wymaga ubezpieczenie społeczne komandytariuszy w spółkach komandytowej i komandytowo-akcyjnej. W klasycznym modelu spółki komandytowej komandytariusz jawi się jako zupełnie bierny „obserwator” funkcjonowania spółki, którego status zasadza się na zagwarantowaniu osobistej odpowiedzialności z sumy komandytowej oraz wniesieniu wkładu ${ }^{31}$. W związku z tym obowiązek ubezpieczenia społecznego mógłby ograniczać się do komandytariuszy posiadających — na mocy decyzji wspólników — prawo prowadzenia spraw spółki i (lub) jej reprezentowania. Ponadto skorygowania wymaga pozostawienie poza ubezpieczeniami społecznymi komplementariuszy w spółce komandytowo-akcyjnej, co wydaje się pochodną powierzchownej oceny charakteru tej spółki.

Zarówno obowiązek podlegania ubezpieczeniom społecznym, jak i okres podlegania tym ubezpieczeniom powinien być powiązany z prowadzeniem przez

31 A. Kidyba, op. cit., s. 333. 
spółkę działalności gospodarczej, które to pojęcie należy odnosić do sfery faktu, podobnie jak w przypadku osób fizycznych prowadzących działalność gospodarczą na podstawie wpisu do ewidencji tej działalności. Obecny stan prawny nie upoważnia do określenia takiego powiązania, a co najmniej wywołuje daleko idące wątpliwości, co skutkuje niepewnością prawną.

Nie bez znaczenia jest również wzgląd na zrównanie położenia prawnego osób fizycznych prowadzących działalność gospodarczą na własny rachunek oraz osób będących wspólnikami spółek prawa handlowego. Wspólnym ratio legis objęcia tych dwóch grup ubezpieczeniem społecznym jest prowadzenie działalności zarobkowej typu gospodarczo-prawnego. Trudno wskazać racjonalne przyczyny uzasadniające sytuację, w której punktem odniesienia obowiązku ubezpieczeniowego pierwszej z wyróżnionych kategorii jest aktywne (faktyczne) prowadzenie działalności gospodarczej, w wypadku zaś osób zaliczanych do drugiej grupy wystarczy bierny (formalnoprawny) status wspólnika spółki handlowej, nawet jeżeli nie prowadzi ona faktycznie działalności gospodarczej.

Wspólnik spółki kapitałowej nie wykonuje, co do zasady, osobistej pracy lub działalności zarobkowej na rzecz spółki. Jego udział w spółce ma charakter kapitałowy. Oznacza to, że nie ponosi on odpowiedzialności za zobowiązania spółki, a jego ryzyko jest mierzone wartością wniesionego kapitału. Ubezpieczeniu społecznemu powinien podlegać zaś nie kapitał, lecz praca lub działalność zarobkowa. Dlatego obowiązkowe ubezpieczenie społeczne w grupie wspólników spółek kapitałowych może stanowić jedynie wyjątek od reguły, usprawiedliwiony charakterem więzi wspólnika ze spółką. Wprowadzenie takiego wyjątku jest zasadne w przypadku wspólników prostych spółek akcyjnych, których wkład do spółki polega na świadczeniu pracy lub usług (art. 8 ust. 6 pkt 4a u.s.o.s.). Kwestia staje się bardziej dyskusyjna w odniesieniu do wspólników jednoosobowych spółek z ograniczoną odpowiedzialnością. W każdym jednak razie opowiadam się przeciwko dalszemu rozszerzaniu obowiązkowego ubezpieczenia wspólników spółek kapitałowych ${ }^{32}$. Jedynym uzasadnieniem tego obowiązku nie mogą być względy o charakterze czysto instrumentalnym, podnoszone przy jego wprowadzeniu. De lege ferenda bardziej odpowiednie wydaje się poprzestanie na dobrowolności ubezpieczenia społecznego tej kategorii wspólników, jednak zagadnienie to wymaga szczegółowych rozważań, które przekraczają zakres niniejszego opracowania.

32 W podobnym kierunku zmierza powołane orzeczenie Sądu Najwyższego z dnia 17 października 2017 roku, II UK 451/16, w którym sprzeciwiono się rozszerzeniu na drodze wykładni obowiązku ubezpieczenia społecznego na dominującego wspólnika dwuosobowej spółki z ograniczoną odpowiedzialnością oraz zwrócono uwagę na brak pojęcia dominującego („niemal jedynego") udziałowca w prawie ubezpieczeń społecznych. Odmiennie Z. Hajn, op. cit., s. 199. Por. też wyroki SN z dnia 7 kwietnia 2010 roku, II UK 177/09, LEX nr 599767; oraz wyrok SN z dnia 3 sierpnia 2011 roku, I UK 8/11, OSNP 2012, nr 17-18, poz. 225. 


\title{
THE STATUS OF A PARTNER IN A COMMERCIAL PARTNERSHIP AS A BASIS OF SOCIAL INSURANCE
}

\author{
Summary
}

The author analyses the status of a partner in a commercial partnership in the light of the scope of a statutory social security scheme. The text shows that a legislator has no clear idea of the legal regulation. The scope of compulsory social insurance should be corrected in respect of the partners in a limited partnership and private partnership unlimited with share capital. The status of the partner treated as a basis of compulsory social insurance should depend on whether a partnership or a company actually carries out economic activity. In the author's opinion there is no need for social insurance of the capital. Therefore the compulsory social insurance of the partners in joint stock companies may be accepted only by way of exception.

Keywords: statutory social security scheme, compulsory insurance, commercial partnership, joint stock company, partner, economic activity

\section{BIBLIOGRAFIA}

Bielski P., Objęcie wspólników spółki jawnej prowadzacych działalność gospodarczq obowiązkiem ubezpieczenia społecznego, „Prawo Spółek” 2006, nr 9, s. 2-12.

Bielski P., Obowiazek ubezpieczenia społecznego wspólników spółek handlowych — problem modelu regulacji prawnej, „Rejent” 2003, nr 7-8, s. 41-56.

Gudowska B., [w:] Ustawa o systemie ubezpieczeń społecznych. Komentarz, red. B. Gudowska, J. Strusińska-Żukowska, Warszawa 2011.

Hajn Z., Zatrudnienie (się) we własnym zakładzie pracy w świetle ustrojowych zasad prawa pracy, [w:] Współczesne problemy prawa pracy i ubezpieczeń społecznych, red. F. Florek, Ł. Pisarczyk, Warszawa 2011.

Kidyba A., Handlowe spótki osobowe, Warszawa 2013.

Lewandowski R., Polska koncepcja legislacyjna spółki komandytowo-akcyjnej, Warszawa 2007.

Szumański A., [w:] Kodeks spółek handlowych, t. 1. Przepisy ogólne. Spółki osobowe, red. S. Sołtysiński, A. Szajkowski, A. Szumański, J. Szwaja, Warszawa 2012. 